\title{
EDITORIAL
}

\section{INCREMENTO DO PROGRAMA DE CONTROLE DA DOENÇA DE CHAGAS NO BRASIL}

A Superintendência de Campanhas de Saúde Pública (SUCAM) do Ministério da Saúde, está incumbida de executar a Expansão do Programa de Controle da Doença de Chagas. Esta expansão era, há muito tempo, sonhada por todos que de uma forma ou de outra, acompanham ou participam do combate a esta doença.

Desde 1912 o próprio Carlos Chagas apregoava a necessidade de atuação mais efetiva e abrangente dos órgãos responsáveis pelo trabalho de controle da endemia pois está comprovada a efíciência da técnica que vem sendo empregada.

Muitas vezes, os discursos de prioridades não são acompanhados, na prática, dos recursos financeiros necessários. Isto vinha ocorrendo con relação à doença de Chagas. Até que, em 1983, o governo brasileiro tomou a decisão política de encarar o problema de forma decisiva.

Para tanto, foi assinado um contrato entre a SUCAM e o Banco Nacional de Desenvolvimento Econômico e Social (BNDES) destinando $10 \mathrm{bi}$ lhões de cruzeiros provenientes do FINSOCIAL, para, complementando o orçamento do órgão, permitir a pretendida expansão. Cerca de dois milhões de $\mathrm{km}^{2}$, abrangendo dois mil municípios de 19 estados serão trabalhados, beneficiando 47 milhões de pessoas.

Depois do sucesso no controle da paralisia infantil no Brasil, através dos dias nacionais de vacinação, o Ministro da Saúde, Waldyr Mendes Arcoverde, consegue atingir mais uma grande meta de sua administração: viabilizar o controle da doença de Chagas. A importância desta decisão fica ressaltada pelo fato de que a prevalência da infecção chagásica existente no país, com cerca de 5 milhões de brasileiros infectados, traz incalculáveis prejuízos sociais.

\section{BOOST IN THE PROGRAMME FOR THE CONTROL OF CHAGAS' DISEASE IN BRASIL}

The Superintendência de Campanhas de Saúde Pública (SUCAM) of the Ministry of Health is to be responsible for the expansion of the programme for the control of Chagas' disease. For a long time interested workers in this field have hoped for such an increase in control activities.

Since 1912 Carlos Chagas emphasised the necessity for action at a national level to control this important endemic disease utilising the most efficient techniques availabee.

Many times in practice, the discussion of priorities was not accompanied by the necessary financial means. This was the case in Chagas' disease until 1983 when the government took a political decision to try to solve the problem.

To this end a contract has been signed between SUCAM and the National Bank of Economic and Social Development (BNDES) alloting ten billion cruzeiros from the FINSOCIAL (a national health insurance scheme). With this cupital SUCAM will be able to expand its prozramme to begin to cover about two million square kilometres comprising two thousand municipalities in 19 states and assisting 47 million inhabitants.

After the success in the control of poliomyelites in Brasil, by declaring two national vaccination days, the Minister of Health, Waldyr Mendes Arcoverde, has achieved another great step in his administration by making the control of Chagas' disease a possibility. The importance of this decision is illustrated by the fact the 5 million Brasilians infected result in incalculable social handicaps. 
Diante deste quadro, espera-se que num futuro próximo, possamos ter a doença de Chagas sob controle em todo país, resgatando uma importante divida social do governo para com significativa parcela da comunidade brasileira.
Considering this situation we hope that in the near future Chagas' disease will be controlled throughout the country. Such an important contribution by the government will help a significant proportion of the Brasilian community.

José Taquarussú Fiusa Lima

Superintendente da SUCAM 